\title{
Round-Table Discussion
}

\section{研究亡産業化 \\ 一国際フェライト会議に際して}

\section{Fundamental Research and Development \\ -On the International Conference on Ferrite-}

$$
\begin{aligned}
& \text { 出席者 井 梁 大氏 (ソニ一株式会社 社 長) } \\
& \text { 武井武氏（慶応義塾大学名誉教授） } \\
& \text { 山 崎 貞 一 氏 (東京電気化学工業株式会社会長) } \\
& \text { (五十音順) } \\
& \text { 司会者 早川保昌氏（青山学院大学教授） }
\end{aligned}
$$

はじめに

本夕はご多忙の中をさいて推りいただきありがとうごいます．わが国の電気化学界で一つ のエポックを画し，しかも世界で広く使用されているフェライトを中心とし，フェライトの発 明者である武井先生に研究の苦心談を, 山崎会長に注海のものともわからない研究結果をなに ゆえ企業化にふみ切られたかを，さらに井深社長には研究の産業化といら問題についてまずお 話を伺いたい，次に現代の企業は大学の研究に何を望んでいるか，また期待をかけているかど うかといった点について忌たんのないご意見を伺えれげ幸だと存じます．

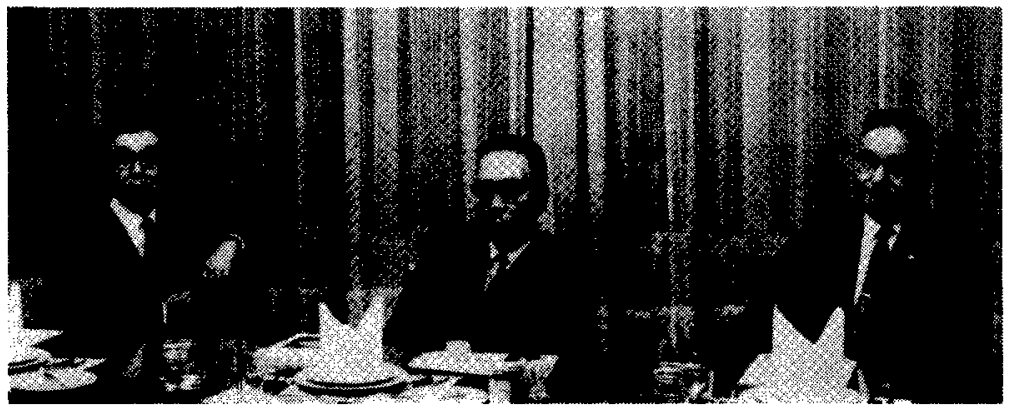

東 京・青学会館にて 


\section{I＼cjkstart国際フェライト会議について}

早川 始めにフェライトを手が付られ，研究を完成さ れた武井先生から本年開催されるフェライト国際会議の 大要をご紹介下さいませんか.

武井 本日は井深, 山崎両氏とこのような座談会がで

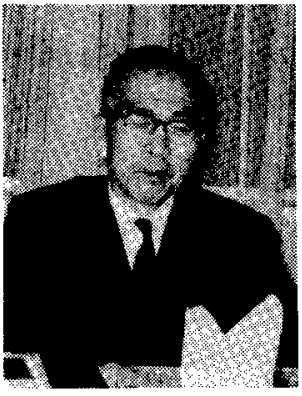
きることをうれしく思いま す、まず皮切りに国際フェラ イト会議 (International Conference on Ferrite (ICF)) について簡単に申し上げま す.フェライトは日本で最初 に開発され，フェライト工業 拉よびその関連工業は今日世 界のトップレベルにあるの で，以前からこのような会議 が日本で開かれることを要望する方がたくさんありまし た. そこで一昨年組織委員会が結成され，わたくしが委 員長に選ばれて今年 7 月 6 日〜 17 日開催の運びとなりま した. 電気化学協会も重要な協賛団体でございます，京 都の main session では主として学術論文の発表が行な われます．浜松と箱根と仙台では論文発表と討論が行な われます．論文数は予想をはるかに越えて外国から 60 以上の立派な論文が提出されました. 国内のものと合計 して約 170 もの論文が発表されることになりました.

早川 外国からの講演にはどんなるのがありますか。

武井 特别講演に注目す心゙きものがたさくんありま す，たとえば将来の情報処理の寸ぐれた手段となる domain bubble の問題が，その発明者である Dr. Borbeck (Bell Telephone) から話されますので，大いに 期待していただきたいと存じます．電気化学とこの会議 とは大いに関連がありますので多数のご参加を希望いた します。

早川 学術講演だけですか.

武井 京都の本会議の後, 浜松 (磁気記憶), 仙台 (新 しい磁性材料)，箱根 (軟磁性材料) で，特殊のテーマ について討論会を持つ予定です.

\section{II フェライトの開発を回って}

早川 武井先生がフェライトの研究に着手された動機 や目的についてお話し願えませんでしょうか.

武井これまで多くの場所で話しておりますのでまた 同じ話になるかもしれませんが.

井深 武井先生のお話ならば 何度伺っても結構です 站.

武井 加藤与五郎先生が外国雑誌にのっていたフェラ イトというものに着眼されたことがその発端です，当時 フェライトという言葉は少数の物理学者だけが知ってい
たものです. 加藤先生は Chemical and metallurgical Engineering 誌上で亜鉛や金の際に亜鉛フェライトが生 成されて抽出のガンになっていることを知り，これの除 去を考えられたことに始まります．たまたまわたくしが 磁性の研究をしていたところからこの研究をわたくしに 命じられたわけです．この時代には現在のような用途が 開かれるとは誰も思ってはいませんでした。

早川すると亜鉛や金の邪魔物を除去する研究から始 まったわけですね。

武井 亜鉛鉱を焙焼すると亜鉛フェライトが生成し， 硫酸に不溶になって亜鉛のロスが多いわけです.

早川 磁性材料としてではなかったのですか，

武井 磁性その他についてはほんの少し論文があった だけでした。

井深 ハードとソフトの問題は同時に出てきたのです 力.

武井 当時化学者にとって根底にふれると思われるよ らな文献はほとんどなく，フランスでいくつか発表され ていました。それも断片的なるのでした。

山崎それもみな単体でしよう。

武井 むちろん単体で, 化学方程式が書いてある程度 で本当の組成も磁性の測定值などもでたらめでしたここ のことからむっと基礎的な研究をしてフェライトの正体 を知ることが必要たと考えました。

早川それで系統的な研究をなさったわけですね.

武井 そうです. ここで亜鉛, 銅, ニッケル，コバル トママグネシウムなどあらゆるフェライトをつくって， これらの磁性を調べました．熱天びんでコバルトフェラ イトの磁性を測定した際です. 翌日改めて測定しなおし たところ異常を発見しました．不思議に思って正確に测 定を行なったところ高温で特別に強く磁化されることが わかりました．磁気臨界点付近で著しく強く磁化される という新しい現象を見いだしたわけです．この現象をど のように解积するかで随分悩みました，化学者としてど のように対処すべきかを考えました．ついに理論的研究 をやめて応用を考えたのです．わたくしには物理現象は わかりませんからますす磁石に目をつけ小さな磁石をつ くってみました.

早川 粉末を焼結したのですか。

武井 コバルトフェライトをかためて焼結して高温か ら磁場で冷却すると強い磁石になったわけです.この磁 石はいまでも記念に持っています，磁場内で高温から冷 却するとこれまで知られたものとは異なる性質の磁石が 得られたのです，そこで意を決して，新しい磁石として 応用することに踏みきったわけです．これを加藤先生に お見せしたところ鋼磁石は 1 ton 200 円でできるが，そ れはいくらでできるかと聞かれました.

早川 それは昭和何年ごろの話ですか。 
武井 昭和 6 年です. コバルトフェライト 1 ton はと ても200 円ではできませんが，KS 銅に比してはるかに 大きな抗磁力の値を示しました. これを先生の前でデモ ンストレーションし, やっとコバルトフェライトが磁石 として優秀であることを認めてもらいました.

早川 それは $\mathrm{MK}$ 鋼以前の問題ですか. またそのこ ろは金属以外の磁石はなかったのですか.

武井 まだいずれもなかったときです，KS 磁石が知 られていただけです。これりり強い磁石として特訴をと り，随分苦労してフェライト磁石を完成したわけです. 同時にわたくしは基礎研究を続け，フェライト単体壮か りでなく,2種のフェライトの固溶体一と研究を進め,亜 鉛銅フェライトがケイ素銅板と同様の磁気履歷現象を示 すことを見いだしましたこれも特許としたわけです。

早川 昭和何年ですか.

武井 昭和 6 年 12 月です. これらの研究は多くの幸 運に恵まれたものです。一般に発明には創意工夫と勘と 決断の三つが必要ですね。決断がなければ駄目ですね.

早川 決断とはどらいうことですか.

武井 研究者が優柔不断では䭾目ですね，自分で決断 して研究を行なわなければならないわけです。これは若 、研究者にも是非言っておきたいことです，わたくしの 場合には加藤先生はしめ周囲の方が後援して下され応用 研究の道が開けてきました，三菱電機や TDK がバック アップして下され，また河合氏や山㱦氏のような優秀な 研究者が熱心に協力してくれたわけです.

\section{III 研究の企業化}

早川 山崎さん. TDK を創立してフェライトの生産 を始められたときはどのような応用を考えられていたわ けですか.

山崎 コバルトフェライトが KS 鋼より溞い磁石であ

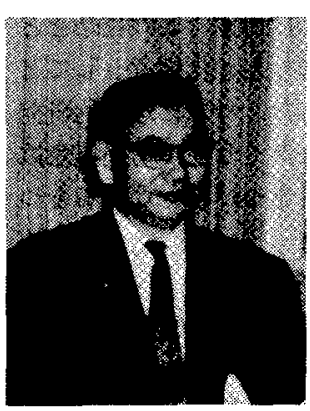

ることに発明者は興味をもた れたことと思います. 昭和 10 年三菱電機が OPマグネット として使用し始わたが，ソフ トの方は忘用がかからなかっ たわけです．たまたま富士電 機が搬送電話線に使う鉄心を Siemens より輸入していた が，この鉄心の代わりにフェ ライトを使おうということに なりかたくしが昭和 10 年大学杂業と同時に同社に入 社し翌年入営するまでこの研究に從事していましたと ころが同社は企業化には踏み切れなかったので，すでに 昭和 10 年 12 月 7 日に設立されていた TDK が富士電 機に代わりフェライトの企業化を行なうことになったわ けです.
武井 要するに富士電機が企業化に踏み切りか好たの を TDK で手がけるようになったわけです。

山崎 以まから若えるとセットメーカーがこの種の素 材を企業化してもどれはど発展したかは疑問ですね.こ れだけを専門に発足した東京電気化学では用途もわから ないままにフェライトを造って種々のところに持ち歩い たわけです.

井深 ものができてしまえば need が出てくるわけで すが，ものができる前ですから随分苦労されたことでし 上 $う$ 小.

武井 性質だけがわかっていて応用の見通しも十分で ないのに会社を始めたのですから冒険だったので苦労さ れたようです。

山崎 昔から運, 根, 鈍といいますが非常に幸運もあ りましたが，命ぜられたものに食いついていたわけで 寸. 応用がわからないが何とかなるだらうと思っていま した.

井深 もう一つ悪いことは日本で生れたものはどんな 良いものでも評価しないのです。

早川それはありますね.

井深 外国でできたものにはとびつきますが，日本に 生れたものを育てようとする力はありませんでしたね。 一度外国を通ってこないと䭾目です㸚。

早川も5かるかどうかわからずにご苦労なさったわ けですね.

并深 どこが最初に採用しましたか.

山崎 最初は安立電機で, 船舶無線の IFT (100キロ サイクル）に用いました. 昭和 13 年のことです.

早川 どのくらいの量ですか.

山崎 何百個のオーダーです，目方にしたら知れたも のです.

早川 その他はどんなところでしたか.

山崎 昭和 15 年松下電器がラジオの同調装置に使お うとしてくれました．従来 C同調（バリコン）を使用し ていたのを，L同調で行なうために $10 \phi \times 40 \mathrm{~mm} \mathrm{のコ}$ アーによる周波数選択器の構想を考えられて大量の注文 をいただきました.これはバリコンのアルミニウムが当 時入手困難のためでしたが，戦争となりこのラジオは一 つも市販されておりません。

早川 どのくらいの数出ましたか.

山崎 約 1 万個です，重量にすれば，それほどでもあ りません。

早川 録音テープはいつごるから始められたのです 加.

山崎 それはずっと後ですが，昭和 13 年ごろ映画の フィルムにフェライト粉末を㙦って音を出そうという考 えはございました。

武井 わたくしもフェライトディスクで録音を試みま 
したがうまく行きませんでした.これが成功していれば 世界最初のものだったでしよう。

井深 IAG が始めたのが 1936 年です.

早川 先日の新聞紙上でソニーが亜鉛一空気燃料電池 を開発された記事を拝見しました.トップレベルの研究 基盤となっているテープ開発のご苦心談を㧍聞かせ下さ $\checkmark$.

井深 初めはNHKの仕事をしていたが，何か枋販の

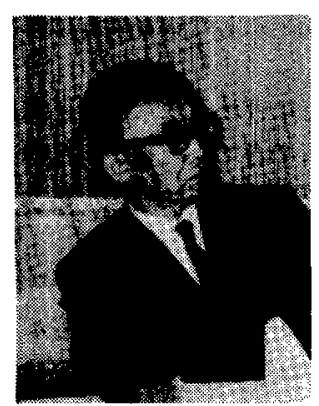

仕事をしなければならないと

考え，ワイヤーレコーダーの

研究をしました．その当時た またまアメリカの Webster 製のテープレコーダーを入手 し性能の良いのに警きテープ レコーダーを開発すべきだと 考えたわけです。

早川 何年ごろですか. 井深 昭和 23 年でした.

まだプラスティックなど手に入らないころでしたからセ ロフォンをべースとしましたが，七ロファンが硬化でき ず，紙をベースにすることを思いつきました。

早川 粉はどうしました.

井深 OP磁石をやすりでけずって粉にし，ご飯つぶ ののりで紙にはりつけたり，ためきの胸毛のはけで塗る などしてやっとテープを作りました，その後，東工大の 星野教授のお力添えでベンガラをラッカーにシンナーを 入れ，これと一緒にスプレーガンで吹きつけてテープを 作りました．これはかすかに音が出ました。、゙ースにな る紙も業界の協力を得てさらによいものが作られ，接着 剂む開発しよいテープが生み出されてきたわけです.

山崎 ソニーの社長がこんな苦労をされたとはいまの 人たちは想像もできませんね.

\section{IV 企業における研究・大学における研究}

早川 いままでのお話は大学での一教室の基磷研究を 企業が開発することによってフェライト工業ができ上っ たことについてでした. 企業が大きな研究設備と陣容を 持っている現在, 大学の研究者に対して第一線の企業家 の方々はどのように大学に期待を持っているかを端的に お話し願えませんでしょうか。

井深 昔は知識の泉は大学の教授でした. 大学の教授 の指導で産業ができ上ってきました．しかしいまでもこ のような考えをむっているところに大きな問題がありま す. 英国もドイッも 3,4 年前まで大学をそのように考え ていました．企業は大学の研究成果を企業化することに 努めればよかったわけです，大学は企業を見下してお り， Science が Engineering より一段上という考えが 持たれていました，日本もこの気風そっくりです，しか
し現在のように産業が進み競争が激しくなっている時点 では, 一教室での研究成果が産業化され大きな偉力を発 揮することは不可能になっています. 多方面の問題をど のようにまとめていくかがプロジェクトの大きな要素と なってきており，企業は 3 年後， 5 年後といった問題を みずから開拓していかなければならないかけです．企業 が研究, 開発に目ざめたのはナイロンがきっかけだと思 います.

早川そうすると大学における研究には現在期待して いないということですか。

井深 現在企業が大学に求めることはいろいるあると 思いますが，大学の研究の中から企業，産業の種をもら って育てていくという吞気なことはいえなくなっている ことは事赛です.ニードということをきびしく知ってい るのは企業だ上思います．大学でははっきり分けて創造 的な仕事をなさる少数の教授と, 基礎研究を通して学生 をトレーニングしていく多数の教授に分ける必要がある うと考えます，すべての教授が好きな研究を自由にや。 ているという涀在の悪平等はやめるべきだと思います． 大学はや㤝り砤育が主体だと考えます。

早川では大学では現在どのような教育をしたらよい とお考えでしょうか.

井深 いま恃非常に進歩, 変化が速い、トランジスタ 一は実用化されて十数年間にその考え方, 作り方, 材料 などが約 10 種類も変化している。このような問題を大 学が研究して追いかけることは园難ですから教科書など でその歴史をしっかり教えていただき，どのような問題 にも対処できる人間を育てて企業に送り出していただき たいと考えています。

早川 学生の教育についてはどのようにお考えでしょ ら加。

井深 企業化入ってからどら勉強すべきかがわかりま すから，それから大学に入って勉強することも大切だと 思います．つまり社会が何を求めているかを知った人が 学ぶとそれなりの成果が上がるわけです．大学でも実際 に則したトレーニングが行なわれなければならないと考 えます.一つのプロジェクトを通した教育で教育効果は 著しく上がります．万編なく知識を授けただけでは，ま

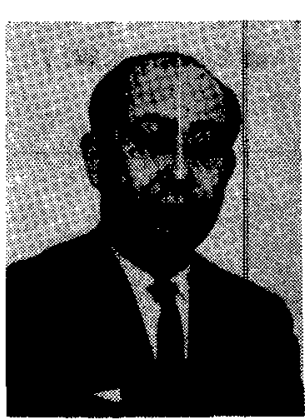
ずいと思いむす。

早川 昔,わたくがアルミ ニウムの会社に居たころは東 工試あたりで数人の人が世界 的な研究を生み出していたの ですが，いまでは何百人もの 企業内の研究者がアルミウム 生産だけにとり組んでいま す.したがって大学などで数 人の研究が工業的な問題にと 
りくんでも何ができるかということになって，大学研究 者がまったく無気力になり創造的な研究をやっていない ように思われます．こんな事情のもとでも大学に多少は creative なるのを期待されておられますか.

井深 したがって大学の教授を大きくこつのカテゴリ 一にわけることが大切だと思いす、一つは creative な 研究者一これはごく少数ですが一に注多積の研究費を与 えて研究に携ってもらい，後の力は一つのテーマーこれ は国全体をいかにしたら幸福にできるか一ということを 考えてやるべきだと思います。

早川 企業内の研究者の養成についてはどのようにお 考えでしようか.

井深 育てるということですが自分で開発していける 人でないと研究者とは言えないと思います，意欲をもっ た人にはしかるべき環境を与えることが大事だと思いま 寸．大学卆業者の教育といらことはナンセスンでしょ

う，仕事を通して自分で教えられて青っていくべきでし ょう.

早川 過保護にはなさらないわけですね.ところで, 武井先生にお聞きしたいのですが，大学に長年おられて これらの点いかがでしょうか。

武井 井梁さんの言われる通りです. それで大学に大 きな悩みがあるわけですね. 大学問題雷議会あたりでも 教育者と研究者という問題に取り組んでおりますね. 奏
際にどうするかが問題です．教育にあたる人と研究にあ たる人とどうバランスするかが重要ですね，学生が人間 としても偉くなり，また研究の厳しさを実際に体得する ためには研究者の真剣なふんい気に触れ，そこで研究の 試練をうけることが必要ですね，そこに悩みがあるわけ です.

井深 わたくしは creative な仕事をなさる方は大学教 授の $1 / 10$ しかいないと思います. 残りの方は教育に従 事されるべきでしょう。この評価は皦しくなされなけれ ばならないと思います。

武井 教授とは権威あるものでなければならないと思 います、教授が雨後の管のようにできて，それが研究費 の山分けのようなことがなされていることに問題があり ますね.

井深 講座制がいけません权。

武井 その通りです. 少数の世間から選ばれた教授が 指導力を発揮するようにならなければいけないと思いま す.

早川 本日は長時間にわたりお話を願いましてまこと にありがとうございました.

その後約 1 時間にわたり幼児教育・英才教育などに関し熱心

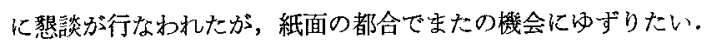

\section{一応用電気化学の国際誌 “Electrochemistry” の発行について}

Electrochemistry」が Chapman and Hall から発刊されることになりました。

同誌㳉 “A Journal mainty devoted to the technological and interdisciplinary aspects of the subject” と副題住さ れるょうに，工業電気化学ならびに境界領域に拉ける電気化学に主体を置いています. 創刊号は本年 11 月，第 2 号注 1971 年 3月に発行の予定です. 日本からは Advisory board に杉野喜一郎氏が参加しています.

採り上げる分野は：Corrosion (electrochemical aspects only), Electrochemical biology, Electrochemistry of the sotid state, Electrometallurgy (electrowinning, electrocladding, electroforming, electroiefining, electroslagging, electromachining),

Electrophoretic doposition, Power sources, Electrochemical engineering, Electrosynthesis, Electroanatysis 形式忙 : Short technical notes and extended abstracts, Papers (including collections fom meetings), Reviews/reports (including instructinal abstracts), Electrochemical Lata Summaries, Letters to editor Editor : Dr. D. Inman Department of Matallurgy Imperial College London, S.W. 7 